\title{
A erradicação da miséria: um problema ambiental central
}

\section{PAULO NOGUBIRA-NeTO}

A

Conferência Rio-92 foi convocada pela Asscmbléia Geral das Naçóes Unidas para resolver alguns problemas ambientais da maior importância. O agravamento dessa situação poderia conduzir o mundo a desastres ecológicos sem paralclo na história do Planeta.

O primeiro, e maior desses problemas, é o resultante das mudanças climáticas que já estáo em curso. De 1980 a 1990, tivemos os 7 anos mais quentes do século. Essa situação é causada pelo chamado "efcito estufa". O uso desordenado de combustíveis fósseis (carvāo c petrólco) aumentou muito o teor de dióxido de carbono na atmosfera. Esse gás devolve à superfície do Planeta grande parte dos raios infravermelhos que a Terra emite em direção ao espaço. Isso provoca um aumento de temperatura na atmosfera terrestre, que a maioria dos cientistas que cstudam a questáo estima em cerca de $3^{\circ} \mathrm{C}$, na média planetária. Será o suficiente para provocar uma alteração geral dos climas das diferentes regióes do Planeta. Assim, áreas que hoje recebem muita chuva poderáo se tornar semiáridas e vice-versa. Tal situação provocará uma grande redução na reprodução de alimentos, pois novos solos agrícolas poderāo levar séculos para se formarem em regióes semi-áridas tornadas chuvosas. Por outro lado, solos que são úmidos e férteis poderão tornar-se muito menos produtivos num clima mais seco.

Essa perda de produtividade, somada à desertificação anual de mais de um milháo de hectares que hoje ocorre e que poderá se agravar, significará no futuro fome e desnutrição maciças. É preciso lembrar que nesse meio tempo a populaçáo humana terá dobrado, ou quase dobrado. Assim daqui a 40 ou 60 anos (aproximadamente) não apenas milhóes, mas bilhôes de pessoas poderão ser atingidas scriamente pela falta de alimentos. Além disso, haverá enorme perda de biodiversidade, pois os ecossistemas terrestres não terão tempo para migrar, acompanhando os respectivos climas. Também as áreas costeiras baixas sofrerão o impacto 
negativo da subida do nível dos mares, que deverá scr de aproximadamente entre $45 \mathrm{~cm}$ e $110 \mathrm{~cm}$.

Ainda no que se refere ao aumento demográfico, ou seja, ao aumento da populaçáo, a taxa atual de $2 \%$ de incremento anual, na média mundial, ainda pode ser considerada como explosiva, pois importaria em dobrar a populaçáo humana do Planeta em cerca de 3 ou 4 décadas. Teríamos, assim, que providenciar uma duplicação da produção de alimentos, o que parece altamente improvável no quadro de mudanças climáticas que afetariam muito desfavoravelmente a agricultura. Scja como for, uma segunda duplicação da populaçáo significaria a morte, por inaniçáo e fome, de bilhóes de pessoas.

A fim de que esse quadro dramático não venha a ocorrer, é necessário desde já fazer grandes esforços no sentido de estabilizar demograficamente o mundo. Contudo, para que isso se torne uma realidade, como já ocorreu em várias partes do Planeta, é indispensável erradicar a miséria. O instrumento para a realizaçáo desse objetivo é a promoçáo de um desenvolvimento auto-sustentávcl, ou seja, não-predatório, que não prejudique as geraçóes futuras.

A erradicação da miséria custará, segundo cálculos apresentados por Maurice Strong, cerca de 127 bilhóes de dólares por ano. Essa quantia, embora pareça muito elevada, é pequena em comparação com o trilhăo de dólares que até recentemente o mundo gastava anualmente em armamentos, principalmente nucleares.

Alguns céticos pensam que o Primeiro Mundo jamais irá gastar grandes quantias em benefício do Tercciro Mundo. No entanto, se acaso não houver altruísmo suficiente para isso, haverá, contudo, razões cgoísticas de sobra. É impossível às naçóes ricas construírem novos muros de Berlim em torno dos seus territórios, para evitar, agora ou no futuro, uma invasáo das multidóes inconformadas com a sua situaçáo e que procuram desesperadamente emigrar. A única soluçáo para o Primciro Mundo, e para toda a Humanidade, será dar emprego e clevar o nível de vida das populaçóes pobres, nos seus próprios países ou regiôes de origem.

Todos nós temos componentes comportamentais egoístas e outros altruístas. O imperativo da erradicação da miséria atende a ambos. De um lado, evitará que o Planeta se torne um grande Haiti, erodido, desflorestado, superpovoado, paupérrimo, violento. O Haiti deve ser resgatado e reabilitado ao invés de ser estendido a todas as naçóes. Por outro lado, será graças ao nosso componente comportamental altruísta que a Humanidade encontrará a principal motivação para agir solidaria- 
mente, de modo a erradicar a miséria. No plano teológico, o mandamento do amor ao próximo deve ser entendido de modo a também abranger as geraçóes futuras. No plano das ações concretas, cstas somente serão possíveis e eficazes se todos os povos do plancta se entenderem bem entre si.

Embora os primeiros resultados concretos, no que se refere a fundos, se resumam, ainda, a cerca de 8 ou 10 bilhóes de dólares, todo um mecanismo começa a se movimentar para atingir o grandc objctivo de acabar com a miséria e melhorar as condiçôes ambientais do Plancta. Durante a Rio-92, estive com o chefe do setor do Banco Mundial que cuida do meio ambiente. Essa instituiçáo vai se reestruturar para atender de modo mais eficiente a esses grandes objetivos. Um dos pontos principais dos novos programas do BIRD é o de incorporar a esses esforços a ação sempre vigilante das Organizaçócs Náo-Governamentais. Principalmente no que diz respeito à fiscalizaçáo do emprego de recursos vultosos, as ONGs poderão dar uma colaboração de decisiva importância. Elas constituem um baluarte na luta contra a corrupção.

A meu ver, a Conferência Rio-92, apesar de suas limitaçóes, representou um notável avanço. Contudo, até que as suas Resoluçốes se transformem em realidades, teremos de conviver com uma situação aparentemente remansosa. É o tempo necessário para reaparelhar c, sobretudo, para reestruturar as instituiçóes que irăo pôr em marcha $\mathrm{e}$ tornar realidade os grandes propósitos da Rio-92.

É preciso, porém, atentar para um detalhe muito importante. Pouco adiantará o emprego de grandes recursos se não houver projetos exeqüíveis e promissores, feitos de modo competente, visando à tomada de medidas concretas. Nesse sentido, o Projeto Floram, do Instituto de Estudos Avançados da USP, feito com a colaboração de outras entidades, deve ser considerado como pioneiro e muito oportuno. É uma iniciativa que atende aos grandes objetivos consensuais da Rio-92: a proteção à biodiversidade $\mathrm{e}$ a reduçáo da amplitude das mudanças climáticas. Trata-se, aliás, de duas questóes estreitamente interligadas.

Sob o aspecto teórico, mas com profundas implicaçōcs e conseqüências práticas, chegou o momento de reformular o que se entende por desenvolvimento auto-sustentável. Quando cssa questáo foi discutida pela Comissão Brundtland, esse tipo de desenvolvimento foi conceituado como o que não prejudica a geração atual $\mathrm{e}$ as geraçốes futuras. Isso sem dúvida é muito importante, mas não basta. Diga-se de passagem que a Cúmissáo Brundtland, da qual participei, procurou e conseguiu um consenso entre regióes e países democráticos e outros que na- 
quela ocasião tinham (e alguns ainda têm) regimes autoritários. Agora chegou o momento de introduzir, no conceito de desenvolvimento autosustentado, o princípio vitalmente importante de que esse tipo de desenvolvimento deve ser estabelecido e dirigido de modo amplamente democrático, o que significa transparência, bem como participaçáo c debate pelas populaçóes nacionais, regionais e locais. Acrescentaria, também, a necessidade de desenvolvimento auto-sustentado ser acompanhado, a cada passo, por estudos de impacto ambiental, sem o que dificilmente seria atingido o objetivo de não prejudicar as geraçóes futuras.

Outro aspecto importante do conceito de desenvolvimento autosustentável foi abordado recentemente no Brasil pelo Prof. Henrique Rattner e pelo deputado Aloisio Mercadante. Trata-se das questốes de desenvolvimento que apresentam importantes implicaçócs quantitativas. Realmente, num Planeta finito e limitado, não é possível tolerar e conviver com o fato de que as populaçóes mais ricas têm níveis de consumo que na prática impediráo às populaçóes mais pobres o acesso a esses mesmos recursos ou produtos. No que se refere à alimentação, felizmente a ciência médica já concluiu que uma dieta excessiva em calorias é altamente prejudicial à saúde e encurta a vida. Mas há ainda muito a fazer no terreno da redistribuiçáa do excesso, não somente no que se refere aos recursos básicos, mas também no tocante a novas $\mathrm{c}$ caras tecnologias.

A questão da explosão demográfica, a ser alcançada pela erradicaçáo da miséria, não mereceu um destaque especial na Conferência Rio-92. Contudo, grande parte dos resultados lá obtidos diz respeito direta ou indiretamente ao desenvolvimento auto-sustentávcl, a ferramenta essencial para erradicar a miséria. Com o uso dessa ferramenta, a Humanidade poderá resolver um problema moral, social e ambiental que é, na verdade, essencial para evitar que o Planeta se degrade profundamente.

Paulo Nogueira-Neto é professor visitante da Área de Ciências Ambientais do Instituto de Estudos Avançados da USP.

Comunicação apresentada no workshop "Ecos da Eco 92" realizado pela SBPC com o apoio do IEA nos dias 13, 14 e 15 de julho de 1992, em São Paulo. 